\title{
PI 3-kinase and disease
}

\author{
Lewis C Cantley \\ From Metabolism, Diet and Disease 2014: Cancer and metabolism \\ Washington DC, USA. 28-30 May 2014
}

Phosphoinositide 3-Kinase (PI3K) is a central enzyme in a signaling pathway that mediates cellular responses to insulin and other growth factors. This enzyme phosphorylates the 3 position of phosphatidylinositol-4,5-bisphosphate to produce phosphatidyl-inositol-3,4,5-trisphosphate ( $\left.\mathrm{PIP}_{3}\right)$ at the plasma membrane. A number of signaling proteins, including the Ser/Thr protein kinases, AKT and PDK1, contain pleckstrin homology domains that bind specifically to $\mathrm{PIP}_{3}$. Thus, the generation of $\mathrm{PIP}_{3}$ at the plasma membrane in response to activation of PI3K by growth factors results in the initiation of downstream Ser/Thr phosphorylation cascades that control a variety of cellular responses. The signaling pathway downstream of PI3K is highly conserved from worms and flies to humans and genetic analysis of the pathway has revealed a conserved role in regulating glucose metabolism and cell growth. Based on deletion of genes encoding the catalytic or regulatory subunits of PI3K in the mouse, PI3K mediates insulin dependent regulation of glucose metabolism, and defects in activation of this pathway result in insulin resistance. In contrast, mutational events that lead to hyperactivation of the PI3K pathway result in cancers. Activating mutations in PIK3CA, encoding the p110alpha catalytic subunit of PI3K or inactivating mutations in PTEN, a phosphoinositide 3-phosphatases that reverses the effects of PI3K, are among the most common events in solid tumors. PI3K driven tumors are FDG-PET positive and turning off PI 3-Kinase with PI3K inhibitors that are in human clinical trials results in an acute decline in FDG-PET signal that precedes tumor shrinkage. Importantly, there is increasing evidence that some tumors express high levels of insulin receptor and activate PI3K due to elevated serum insulin in patients with insulin resistance. These results suggest that elevations in serum insulin may partially explain the link between obesity, diabetes and cancers. The role of PI3K inhibitors for treating cancers in mouse models and in human trials will be discussed.

Weill Cornell Medical College, New York, NY, USA
Acknowledgement

Supported by JSPS Research Fund.

Published: 28 May 2014

doi:10.1186/2049-3002-2-S1-030

Cite this article as: Cantley: PI 3-kinase and disease. Cancer \& Metabolism 2014 2(Suppl 1):030.
Submit your next manuscript to BioMed Central and take full advantage of:

- Convenient online submission

- Thorough peer review

- No space constraints or color figure charges

- Immediate publication on acceptance

- Inclusion in PubMed, CAS, Scopus and Google Scholar

- Research which is freely available for redistribution
( Biomed Central 